\title{
Globalization and Internationalization: ISO 21001 as a Trigger and Prime Key for Quality Assurance of Higher Education Institutions
}

\author{
Mustafa Kayyali ${ }^{1}$ and Arti Khosla ${ }^{2}$ \\ ${ }^{1}$ Manager of International Relations Unit, Academy of Health Sciecnes, Syria \\ ${ }^{2}$ Founder \& CEO- COAE International Centre of Assessments for Excellence, India
}

Correspondingauthor:pr@hsacademy.org

Received: 20 May, 2021

Revised: 03 Jun, 2021

Accepted: 19 Jun., 2021

\begin{abstract}
Talking about quality in higher education is not a new matter, as it was previously discussed by many researchers about the importance of implementing a specific quality system in higher education institutions to ensure preserving the quality of the educational process provided. Accordingly, many quality bodies have appeared in all countries of the world, which operate according to specific (almost similar) protocols to ensure the safety of educational outcomes and that the information reaches the student. Those protocols aim to guarantee that the graduate benefits from the courses they had studied and applied that information in the labor market while ensuring that this information is relevant and compatible with the labor market requirements. In a later period, and with the advent of time, new and specific terms emerged that clarify the differences related to the academic accreditation of educational institutions, including programmatic, institutional, regional, and local accreditation (and we will talk about the difference between them later in the research) and with the passage of years, a new concept emerged that the International Organization for Standards ISO introduced, namely: Management Quality Management System for Educational Institutions ISO 21001. This standard appeared in late 2017 and early 2018 and is similar in its work and goal to institutional accreditation provided by bodies for educational quality assurance and control in the European Union, USA, Canada, and all other countries worldwide.

Objectives: The ISO 21001 standard is considered one of the essential protocols concerned with monitoring and developing the performance of educational institutions, monitoring the system and methodology of their work, and ensuring educational outcomes. Perhaps one of the most critical sectors benefiting from this standard is the higher education sector, with its universities, colleges, higher institutes, and vocational education institutions. This research aims to clarify the importance of higher education institutions applying the ISO 21001 standard and the logical, helpful and beneficial role that it can play in developing and improving the work of the educational institution and developing the methodology and mechanism of its performance. This research provides a comparison and approach between academic accreditation standards for several quality bodies worldwide, compares them with ISO 21001, and shows the similarity
\end{abstract}

How to cite this article: Kayyali, M. and Khosla, A. (2021). Globalization and Internationalization: ISO 21001 as a Trigger and Prime Key for Quality Assurance of Higher Education Institutions. IJASE., 9(01): 67-96. 
and differences between them. Besides, this study explains and compares the institutional and programmatic accreditation on the one hand and the quality assurance provided by the ISO 21001 system on the other.

Keywords: Higher Education, Quality Assurance, Quality Control, Accreditation, Certification, HEIs, ISO 21001, COVID-19

It would probably not be difficult to obtain consensus on the suggestion that universities should aim for high quality in both teaching and research. But, it is much more challenging to define what quality is, how it can be identified and how it can be measured. This is evidenced by the fact that some of the key policy documents on quality assurance for universities go into much detail about how quality assurance should be made without specifying the main meaning of the concept of quality. The concept of quality assurance in education is challenging to define. Increasing graduation rates and educational attainment levels will not achieve much if students do not learn lasting value. By focusing heavily on graduation rates and levels of achievement, policymakers of higher education institutions ignore the basic foundations and pillars on which the entire educational process must be built. The progress of education without supervision and graduating students without making sure of the outputs they obtained, but the basic lesson is to ensure the quality of these outputs and their conformity with the labor market. What employees, students, and employers perceive as high quality must be defined for universities to be able to express their offerings. Likewise, helping students develop graduate skills and traits that employers value is essential. Higher education institutions focus on continuous and permanent development to improve the quality of the educational outcomes they provide and improve all components of the educational process in a way that leads to the achievement of the institution's strategic plan. Quality in education can be viewed as that process that aims to improve the educational process and achieve a qualitative leap by applying a package of academic procedures and regulations and documentation of various educational programs. Quality is a management system that is based on a set of values and relies on employing data and information on employees with the main intention of investing their qualifications and intellectual capabilities in the various levels of organization in a creative manner that, by its end, leads to the continuous improvement of the organization. Quality in the educational field refers to a set of standards and procedures whose implementation aims at constant improvement in the educational product, and also refers to the specifications and characteristics expected in this product and in the processes and activities through which these specifications are achieved with the availability of integrated tools and methods that help educational institutions To achieve satisfactory results. Some argue that the foundations of our current interest in quality in higher education date back, at the very least, to the Middle Ages when professors at the universities of Bologna and Paris were placed under a charter organized by student unions to ensure the lives of teachers up to the university's detailed bylaws and provided scholarly value corresponding to the fees students paid. However, while there were some significant developments in university structures and the way they functioned in the nineteenth century in Europe and the United States, it was not until the latter part of the twentieth century that the concern for quality assurance and accountability was the focus of the acute focus it has today.

\section{Historical Development}

Starting in the 1960s, higher education institutions began to open their doors to provide opportunities for 
a wide range of students in a different way than they were before. In a previous period, higher education institutions only met the needs of elite students and not others who had exclusive access to higher education. This "inflation" of education has led to concerns in society at large that the quality of higher education programs will be jeopardized and not meet previous standards. By the 1980s, governments conflicted with these and other questions about the quality of the outputs of the many higher education institutions they created to cater to the growing number of students. The dilemma was how to ensure quality and at the same time, how to continue to meet the need for large numbers of graduates to lead the new information-based economies. At that point, there was an ideological shift in the thinking of governments around the world about their role and the realization that instead of trying to organize their work towards achieving quality in the same way as medieval student unions did, it would be possible to assess the quality of institutions and programs through a process. They detailed peer review. And from here arose, often with government assistance, those agencies that work in the field of evaluating institutions and programs and reporting on their assessments - and disseminating them to all. These agencies are referred to as "international quality assurance agencies," or quality assurance agencies or international recognition and accreditation agencies.

Since the end of the eighties of the last century, higher education has been reconfigured as a result of pressures arising from the social and economic change in society, the privatization of education began, and the processes of adding and raising tuition fees for students were made. Higher education's response resulted in a fundamental change - the transition from the elite system to amass system that at least $40 \%$ of the population could access. Quality standards differ in the different fields applied by higher education institutions and according to their monitoring systems. Still, they all meet in many specifications and standards that are based on fundamental principles and pillars, all concerned with the quality of the final product through the various stages of production. Quality in education does not deviate from this framework, as it is concerned with the characteristics of graduates from schools and the results of their academic achievement through various stages and processes and the ability to overcome all problems, obstacles, and obstacles that may hinder their path.

With time, many institutions dealing with the issue of quality appeared, which became providing assessment, recognition, and licensing services to higher education institutions around the world. The recognition criteria are generally based on several issues, perhaps the most prominent of which is the quality of curricula and curricula, the quality of the infrastructure, the competence of the faculty members, the selection of appropriate human resources, the continuous improvement of the educational process, and the satisfaction of the relevant components associated with the educational process. We will clarify these differences in a later stage of the research.

\section{ISO International Organization for Standardization}

A non-governmental, non-profit service organization that works to raise standards, set standards, foundations, tests, and grant certificates related to them to encourage trade in goods and services on a global level in various fields ${ }^{[44]}$. This organization includes representatives from most countries of the world. According to the ISO 8402 standard, quality is defined as integrating the features and characteristics of a product or service to meet specific or implicit needs and requirements. The members of the organization are the standards organizations of the 165 member states. With a rotating membership of 20 member bodies, the FAO Council provides guidance and governance, including setting the annual budget for the 
central secretariat. The Technical Board is responsible for more than 250 technical committees that develop ISO standards. ISO is the world's largest developer of voluntary international standards and facilitates global trade by providing common standards between countries. More than twenty thousand standards have been developed, covering everything from manufactured products and technology to food safety, agriculture, healthcare, education, and all areas of health, intellect, and knowledge.

The International Organization for Standardization was started in the 1920s as the International Federation of National Societies for Standardization (ISA). It was suspended in 1942 during World War II. Still, after the war, the ISA was contacted by the recently formed United Nations Standards Coordination Committee (UNSCC) with a proposal to form a new global standards body. In October 1946, delegates of the International Federation of National Standardization Societies and the United Nations Standards Coordination Committee from 25 countries met in London and agreed to join efforts to create the new international organization for standardization. The new organization officially began its operations on February 23, 1947. In 1987 the ISO Standards Committee headed by Canada developed the international quality standard based on the British standard BS 5750, which was the first of the ISO 9000 series, and since this year the series has grown and developed that includes associated guidelines that apply to Specific industries and end The ISO 9000 consists of two types of quality management standards comprising requirements and procedures that represent an international consensus on good management practices.

In terms of the direction of the International Organization for Standardization ISO, it has the support of national standards bodies in more than 150 countries around the world, and thus it is the logical choice for any company or institution that has members or clients and wants to operate in the international standards environment. The ISO standards and specifications do not describe the details of quality systems, but rather set basic guidelines for international quality in various sectors of production for goods and services, and it takes into account and is concerned with review activities to improve the methods of applying quality standards and their system. . It also focuses on training workers in enterprises producing goods and services as the cornerstone of the application and implementation of the international quality standards system.

Although the number of companies and organizations that obtain a quality certificate is low, whether in Europe or America, it is increasing considerably due to the growing awareness of the benefits of getting ISO certification in marketing goods and services, especially marketing them internationally. With time, ISO standards could become the final rule for quality in international markets, and they became mandatory standards for some commodities in the European Union. Many US government institutions and organizations and most US manufacturers have begun to voluntarily choose ISO specifications, increasing the number of customers, increasing their profits, and winning the most significant part of the international market.

The adoption of the quality management methodology is considered a strategic change tool to provide products and services to many companies and organizations. ISO 9001 is the appropriate framework for administrative processes in general. It helps ISO 9001 to determine the most suitable policies and procedures necessary to achieve the quality of services and products and that the development of the quality management system will achieve success At all levels while ensuring the provision of services and products that meet the requirements of international standards.

Using standards helps create safe, reliable, and good-quality products and services. Standards help companies increase productivity while reducing errors and waste. By enabling direct comparison of products from different markets, it facilitates companies' entry into new markets and assists in developing 
global trade on a fair basis. Standards also protect consumers and end-users of products and services, ensuring certified products meet minimum internationally established standards.

\section{Sectors covered by ISO}

As mentioned earlier, roughly, ISO standards cover everything that can be covered in all intellectual, knowledge, commercial, industrial, medical and educational fields. Besides, the International Organization for Standardization undertakes periodic updates to the standards applied by it, whereby an update to the standard is issued and developed following the market need and the beneficiary's desire, and these changes intersect with international systems and standards. Here we list the essential standards covered by the ISO system:

ISO 9001 ${ }^{[26]}$ : It is the international quality standard for a comprehensive quality management system, and it was initially established in 1987, and several amendments were made to it in 1994, 2000, 2008, and 2015, which is the most recent. This standard is achieved in any type of nature, region, process, or size. It is a widely widespread standard and defined by many countries as one of the requirements for institutions and organizations' work, and India is one of these countries.

$\square$ ISO $14001^{[45]}$ : This standard is used to improve the organization's environmental performance and define the requirements of the environmental management system. It is also used systematically by the institutions that deal with environmental matters, the institutions that aim to achieve the environmental management systems, and the interested and related parties. The last update of the standard was in 2015.

$\square$ ISO 20000[23]: It is a global standard for information technology that allows organizations to demonstrate their technical development and best practices in IT management. Standardized collateral organizations can achieve evidence-based standards to enhance the continuous transfer of IT departments. The standard was developed during the International IT Management Supplier and turned into a focused differentiator for transferring IT departments.

$\square$ ISO 22000[16]: A food safety management system that can be applied to any organization's food chain industry. It is considered proof that the establishment has a food safety management system. It also provides confidence to the customer about your product. A customer orders safe and healthy food and food processors and requires that the ingredients obtained from their suppliers be safe and healthy for their customers.

$\square$ ISO 27000 ${ }^{[40]}$ : The most appropriate standard for an information security management system by creating a planned management framework to bring data security under the control of rapid management.

$\square$ ISO 13485 ${ }^{[21]}$ : A relatively recent standard that was published in 2016 that deals with the basic requirements of a comprehensive management framework for planning and producing therapeutic tools and includes some basic requirements specified for medical instruments such as autopsy and sterilization.

ISO $29990^{[33]}$ : It is concerned with ensuring the quality of training and informal education. It also promotes transparency and evaluation of the administrative processes of institutions concerned with training and informal education and is seen as a holistic and organized administration of the administrative process. 
ISO 50001 ${ }^{[25]}$ : is the international standard for the energy management system and was issued in early 2011. The management of energy and bio-assets is of exceptional importance in today's situation of abnormal weather and environmental change.

$\square$ ISO $45001^{[10]}$ : It is the international standard related to occupational health and safety. As we know, occupational injuries and diseases affect the economy negatively due to poor health, early retirement, and high insurance premiums. As a result, the International Organization for Standardization has developed Standard 45001, which provides appropriate guidance and instructions to employees, provides a safety framework for them, reduces workplace risks, and provides safer work environments.

$\square$ ISO $31000^{[29]}$ : It is the international standard devoted to risk management, identifying best practices related to risks and obstacles that may be encountered during work.

$\square$ ISO $18091^{[22]}$ : It is the standard that provides a guide and action plan for local governments to deal with the needs and requirements of people at all levels (i.e., strategic, tactical, administrative, and operational) to form a comprehensive quality management system that focuses on achieving local government goals. The comprehensive nature of this system is necessary to ensure that all areas of local government have a specific level of reliability (i.e., operational effectiveness).

ISO $26000^{[11]}$ : It is the standard on social responsibility for companies and institutions committed to operating in a socially responsible manner. It also guides those who recognize that respect for society and the environment is a critical success factor in addition to being the "right thing" to do.

ISO $20121^{[31]}$ : It is the standard for sustainable development. Events and disasters take a heavy toll on resources, society, and the environment and often generate significant waste. In addition to promoting more responsible consumption, this standard has been developed to reduce pressure on local infrastructure and facilities, reducing the potential for conflict in the communities where events are hosted.

ISO $21001^{[43]}$ : It is the standard related to ensuring the quality of educational institutions and their management system, and we will talk about it in this study.

There are many standards for defining international language codes, main colors, currency values, country logos, information technology, public, health, technical, educational, and logistical structures, and so on.

\section{ISO 21001: Certification Protocol}

The structure of the educational institution's management standard 21001 was built according to the basic procedures of the ISO followed in the development of modern international standards by adopting a unified structure at a high level of competence that includes identical basic texts, general terms, and basic definitions aimed at implementing the requirements and enhancing their compatibility, which contributes to achieving complete coordination Between the elements of the educational process, integration of administrative systems, solving problems and difficulties, and saving time and effort ${ }^{[39]}$. The ISO 21001 standard is also considered the standard for dealing with quality assurance in educational institutions and higher education institutions as it represents a common management tool for institutions that provide educational products and services capable of meeting the needs and requirements of learners and other customers and can be viewed as an integrated management system that contributes to the success of the educational institution, its development, and improvement of its work plans. It also forms a stand- 
alone high-level structure management system that targets organizations providing educational products and services and focuses on the interaction between the educational organization and the staff or other learners who define requirements. The standard supports institutions that contribute to the development of knowledge through teaching, learning, or research and mainly aims to enhance learners, other beneficiaries, and employees through the effective implementation of the educational institution management system. Generally, it focuses on improving the system and ensuring compliance with the learners' requirements. Not only that, the standard applies to institutions in which education is not an essential business, such as vocational training departments, vocational education schools, technical schools, and non-formal education institutions. There is an urgent and continuous need for educational organizations and higher education institutions to assess the degree to which it meets other learners' and clients' requirements to improve their ability to continue doing so. This item focuses on the specific interaction between an educational institution, the learner, and other clients. Today, the current educational processes are becoming increasingly focused on co-creation as the traditional customer-supplier relationship is refined into a collaborative partnership. ISO 21001 provides appropriate guidance on how to introduce quality in this challenging new environment ${ }^{[28]}$.

It is important to note that education differs from many other sectors in that a successful educational process increases the chance of a learner's success. However, it does not guarantee this outcome, and the effort and capacity of both the learner and the educational institution are among the critical variables that lead to the success of the educational process. Learning involves the assimilation of knowledge, methods, and skills, and at this point, in particular, the educational organization catalyzes this understanding and provides the framework, inputs, processes, and learning resources for it to take place. However, it is the efforts and ability of the learner that ultimately determine the success of the educational process. The success of the educational process leads to the success of society as a whole, given the close and direct link between the education sector, its impact, and its direct link to all other sectors of life. Thus, applying the ISO standard for the management system of educational institutions aims to achieve this success. This standard aims to improve the work of educational institutions that provide, participate and facilitate the building of knowledge through teaching, training, or research, regardless of type, size, product, and service provided. It also aims to enhance learners' satisfaction, other customers, and employees through the effective application of the electronic management monitoring system, including system optimizations.

ISO 21001 standard aims to achieve the following:

$\square$ Better alignment of objectives and activities with the educational institution's business policy and protocol (including mission and vision).

$\square$ Promote social responsibility by providing inclusive and equitable quality education for all

$\square$ More personalized learning and effective response to all learners, especially those with special educational needs and distance learners

$\square$ Consistent evaluation processes and tools to demonstrate and increase effectiveness and efficiency

$\square$ Increase the credibility of the educational institution

$\square$ The ability to demonstrate a commitment to effective quality management practices

$\square$ Developing a culture of organizational improvement

$\square$ Harmonization of regional, national, open, and private standards within an international framework 
Expanding the participation of interested parties

$\square$ To stimulate excellence and innovation

$\square$ Continuously improving the education system

$\square$ Enhancing the reputation of the educational institution

$\square$ Promote equal opportunities for all students regardless of their religious background, ethnic or cultural origin, gender, or ability/disability

$\square$ Make education more accessible (physical or online settings)

$\square$ More personalized learning and effective response to special educational needs

$\square$ Harmonized processes and evaluation tools to demonstrate and increase effectiveness and efficiency

\section{The protocols that the ISO standard for educational institutions focuses on}

The criteria are as follows ${ }^{[17][46]}$ :

$\square$ Focus on learners, beneficiaries, and those directly related to the educational process: The primary focus of the educational organization management system is to meet the requirements of the learner and other beneficiaries, exceed their expectations, and achieve the goals they focus on.

- Conscious leadership: It is smart and practical leadership that adopts the principle of decentralization in the decision-making based on the involvement of all learners and other beneficiaries in the creation, writing, and implementation of the mission, vision, and goals of the educational institution.

$\square$ Operations: they must be linked, coherent, and based on solid and interdependent foundations that achieve overall the primary objectives of the educational institution and ensure the achievement of its vision, mission, and goals, determine the inputs, and achieve the outputs.

Improvement: Educational institutions focus on the continuous improvement of their work, activities, and programs.

$\square$ Evidence-based decisions: The decision-making or implementation of any task depends on decisions, books, and letters that can be referred to when needed, whether in paper or digital form, and this will lead to the overall analysis of the institution's data, which achieves and leads to the implementation of the desired results of the institution.

$\square$ Communication: The educational institution works to achieve continuous success by implementing and delivering a network of distinctive and strong relationships with the relevant parties and the relationship and affairs of its work.

Social responsibility: There is a direct correlation between the educational institution and the community, and the educational institution cannot work without a direct connection with the district. It is the daughter of this community and its newborn. It must achieve its goals and social responsibility to ensure sustainable work and achieve success in the long term and perspective.

$\square$ Application of the principle of accountability and responsibility at work: Successful institutions are characterized by the application of comprehensive, general, flexible, transparent, and accountable policies to organize and control work, in order to meet the individual and special needs of learners, their interests, abilities, and backgrounds. 
Equality: The equality aspect of an educational institution includes the institution's ability to create a professional, ethical environment in which all concerned parties are treated fairly, avoiding conflicts of interest, equality, and non-discrimination due to any underlying cause.

$\square$ Information security and data protection: the educational institution guarantees the establishment of a safe, effective and specific system to protect the data of all interested and related parties and those related to the educational institution that guarantees the security and integrity of their data. The educational institution deals with this data with care and complete confidentiality without anyone in the institution seeing it except the parties concerned with that.

\section{A comparison between the accreditation standards and the ISO standards}

Academic accreditation is a quality assurance process by which the services and operations of educational institutions or programs are evaluated and verified by an external body to determine whether the standards applied and recognized are being met. If the criteria are met, accreditation status is granted by the appropriate agency. The American accreditation process was developed in the late nineteenth and early twentieth centuries after educational institutions realized the need to improve coordination and expression between higher education institutions, in addition to standardizing requirements between the two levels, as there was a wide range of colleges and universities with different admission requirements, curricula and study periods required to obtain A degree. The lack of global standards has made it difficult for enterprise managers to identify differences between programs in high schools, colleges, and high schools. For institutions, discrepancies in curricula and grades complicate the transfer of credits as students move. Likewise, institutions have had difficulty assessing whether students from other countries qualified for college or graduate school. Colleges and universities have established accreditation bodies as voluntary membership unions designed to ensure the correct educational process in setting curricula and degrees and transferring credit standards through a process that includes review and scrutiny of specialized committees.

First of all, you can see a list of some quality agencies around the world.

\begin{tabular}{llll}
\hline $\begin{array}{l}\text { Sl. } \\
\text { No. }\end{array}$ & Abbr & Insitution & Country \\
\hline 1 & AACSB $^{[1]}$ & Association to Advance Collegiate Schools of Business & USA \\
2 & ABET $^{[2]}$ & Accreditation Board for Engineering and Technology & USA \\
3 & ACEN $^{[5]}$ & Accreditation Commission for Education in Nursing (ACEN) & USA \\
4 & ACQUIN $^{[8]}$ & Accreditation, Certification and Quality Assurance Institute & Germany \\
5 & AHPGS $^{[4]}$ & Accreditation Agency in Health and Social Sciences & Germany \\
6 & AICTE $^{[18]}$ & All India Council for Technical Education (AICTE) & India \\
7 & AQA $^{[47]}$ & Agentur für Qualitätssicherung und Akkreditierung Austria & Austria \\
8 & AQAS $^{[9]}$ & Agency for Quality Assurance through Accreditation of Study Programs & Germany \\
9 & ASIC $^{[3]}$ & Accreditation Service for International Schools, Colleges and Universities & UK \\
10 & CHEA $^{[12]}$ & Council for Higher Education Accreditation & USA \\
11 & EQAA $^{[15]}$ & External Qualification Assurance Agencies & German \\
12 & ETEAC $^{[13]}$ & Education and Training Evaluation Authority Commission & Saudi Arabia \\
13 & HEC $^{[19]}$ & Higher Education Commission (HEC) & Pakistan \\
14 & NAAC $^{[2]]}$ & National Assessment and Accreditation Council (NAAC) & India
\end{tabular}




\begin{tabular}{llll}
15 & NARIC $^{[14]}$ & National Academic Recognition Information Centres & UK \\
16 & NOKUT $^{[34]}$ & Norwegian Agency for Quality Assurance in Higher Education & Norway \\
17 & QAA $^{[38]}$ & Quality Assurance Agency for Higher Education & UK \\
18 & SEP $^{[35]}$ & Secretaría de Educación Pública & Mexico \\
19 & TRACCERT $^{[41]}$ & Training Accreditation \& Certification Organization Canada & Canada \\
20 & UGC $^{[42]}$ & University Grants Commission UGC , India & India \\
21 & YÖK $^{[48]}$ & YÖK - Yüksekögretim Kurulu & Turkey \\
22 & ZEvA $^{[20]}$ & Central Evaluation and Accreditation Agency (ZEvA) & Germany \\
\hline
\end{tabular}

\section{Accreditation Concepts}

When we talk about academic accreditation, we must define some concepts related to accreditation, perhaps the most important of which are the following:

$\square$ Accreditation is a quality assurance process whereby the various services related to students and staff (such as quality of academic programs, staff, etc.) that the college/university provides are evaluated by an accrediting body. The authority determines whether the higher education institution meets the required standards and grants it accreditation status accordingly.

$\square$ Recognition is recognizing the relevant university as an institution authorized to issue diplomas mainly by the competent authorities in the country in which they operate, which are accredited through accreditation or quality assurance institutions, and recognition by the higher education center. "Recognition also means that all requirements are met. Minimum education: On the other hand, the degree awarded to a college or university through the recognition process shows how well the institution is able to maintain the required standards in terms of quality of education, faculty, etc.

$\square$ Certification: This is confirmation by a third party that a product, process, or service conforms to the specified requirements. According to unified, predefined criteria, a non-governmental agency grants the license to recognize a limited period of educational programs demonstrated by the institution. The licensing process goes through strictly legal and standard psychological requirements.

$\square$ Institutional Accreditation: Institutional Accreditation is considered more comprehensive than specialized accreditation and is highly regarded and respected in the higher education scenario. Institutional Accreditation is the status conferred on an institution that is found to meet or exceed established standards for quality education. Institutional accreditation is the comprehensive evaluation of the institution and its academic and administrative effectiveness, emphasizing the robustness of the internal quality assurance system, the available systems, policies, and practices of the institution, and how they affect the quality of all components of the educational process. Institutional Accreditation reviews the academic and organizational structures of a college or university as a whole.

$\square$ Programmatic Accreditation: Programmatic Accreditation (sometimes known as specialist or program accreditation) includes educational standards for a specific program, department, unit, or school that is a subset of a large organization. This means that if a specialized accrediting body accredits a specific program offered by a department/institution; This does not mean that other 
programs of the same department or institution will also be accredited. Accreditation usually assesses the curriculum, students, faculty, administrative structure, and resources available as accreditation bodies wish to ensure that all students have access to the same level of support, supervision, access, and guidance to appropriate program resources. It is not necessary for an institution that obtained program accreditation to obtain institutional accreditation. The reason for this is that it is expensive and takes a long time to achieve it. Program accreditation conducts an in-depth evaluation of specialized or professional programs at an independent college, university, or institution.

$\square$ National Accreditation: Nationwide accredited schools and colleges are those for-profit institutions that offer vocational, professional, or artistic programs. National Accreditation typically provides accreditation for schools that focus on vocational education. Nationally accredited schools generally accept accreditation from other nationally accredited schools and regionally accredited schools. National accrediting agencies have slightly different jobs. As the name suggests, national agencies accredit schools across the country. They usually accredit vocational, technical, or vocational schools for profit. While some agencies, such as the Commission on Professional Schools and Colleges Accreditation, focus primarily on providing institutional accreditation, others, such as the American Academy of Liberal Education, offer institutional and program accreditation.

$\square$ Regional accreditation: is based on regional accreditation bodies in specific regions of the country. These organizations award accreditation to schools, colleges, and universities that demonstrate that their accreditation and grades meet minimum standards. This is a voluntary process that selfregulates the higher education industry. Regionally accredited colleges are the most academically oriented not-for-profit or state-owned institutions. Regionally accredited institutions are reluctant to accept transfer credits from nationally accredited institutions, mainly because the latter did not meet stringent standards for faculty qualifications and library resources. In the United States, regional accreditation agencies serve a specific geographic area, while some provide accreditation services internationally. These bodies are primarily concerned with accrediting academic and notfor-profit schools, rather than technical or business schools.

Here, a comparison can be made between academic recognition and accreditation on the one hand and the ISO system on the other hand. In order to do so, we will take several cases of academic accreditation bodies, each body in a specific region. We will compare them with ISO 21001 to reach a specific result.

1. Accreditation, Certification, and Quality Assurance Institute ACQUIN, Germany

2. ACBSP Accreditation Council for Business Schools and Programs, United States of America

3. The Curacao Accreditation Agency (AAC), Curacao.

4. Accrediting Commission for Community and Junior Colleges (ACCJC), United States of America

5. The New England Commission of Higher Education - NECHE, USA

6. National Assessment and Accreditation Board (NAAC), India

7. Barbaros Accreditation Board, BAC, Barbaros

8. AHPGS Accreditation Agency in Health and Social Sciences, Germany

9. ASIC Accreditation Service for International Colleges, UK. 


\section{Accreditation, Certification, and Quality Assurance Institute ACQUIN, Germany}

Accreditation, Certification, and Quality Assurance Institute is an academic accreditation system established in 2001 due to the European Bologna Process and the upcoming need to ensure the quality of educational programs, undergraduate and postgraduate programs. Accreditation, Certification, and Quality Assurance Institute is a non-profit, member-based organization located in Bayreuth, Bavaria, Germany. The institute operates under license from the German Accreditation Board and is therefore authorized to award its own quality seal to study accredited programs successfully. The institute is re-accredited by the German Accreditation Board. The institute awarded its seal to several European countries, Africa, Asia, the Middle East (Lebanon, Egypt, and Syria), Austria, Switzerland, Hungary, and the United States of America. The institute is funded by membership fees and higher education institutions for the accreditation services provided.

\section{Accreditation Criteria}

\begin{tabular}{|c|c|}
\hline \multicolumn{2}{|l|}{ Accreditation Standards } \\
\hline $\begin{array}{l}\text { Policy for quality } \\
\text { assurance }\end{array}$ & $\begin{array}{l}\text { Institutions should have a policy for quality assurance that is made public and } \\
\text { forms part of their strategic management. Internal stakeholders should develop and } \\
\text { implement this policy through appropriate structures and processes while involving } \\
\text { external stakeholders. }\end{array}$ \\
\hline $\begin{array}{l}\text { Design and approval of } \\
\text { programmes }\end{array}$ & $\begin{array}{l}\text { Institutions should have processes for the design and approval of their programs. } \\
\text { The programs should be designed to meet the objectives set for them, including the } \\
\text { intended learning outcomes. }\end{array}$ \\
\hline $\begin{array}{l}\text { Student-centred learning, } \\
\text { teaching and assessment }\end{array}$ & $\begin{array}{l}\text { Institutions should ensure that the programmes are delivered in a way that encourages } \\
\text { students to take an active role in creating the learning process, and that the assessment } \\
\text { of students reflects this approach. }\end{array}$ \\
\hline $\begin{array}{l}\text { Student admission, } \\
\text { progression, recognition, } \\
\text { and certification }\end{array}$ & $\begin{array}{l}\text { Institutions should consistently apply predefined and published regulations } \\
\text { covering all phases of the student "life cycle,", e.g., student admission, progression, } \\
\text { recognition, and certification. }\end{array}$ \\
\hline Teaching staff & $\begin{array}{l}\text { Institutions should assure themselves of the competence of their teachers. They } \\
\text { should apply fair and transparent processes for the recruitment and development of } \\
\text { the staff. }\end{array}$ \\
\hline $\begin{array}{l}\text { Learning resources and } \\
\text { student support }\end{array}$ & $\begin{array}{l}\text { Institutions should have appropriate funding for learning and teaching activities and } \\
\text { ensure that adequate and readily accessible learning resources and student support are } \\
\text { provided. }\end{array}$ \\
\hline Information management & $\begin{array}{l}\text { Institutions should ensure that they collect, analyze, and use relevant information to } \\
\text { manage their programmes and other activities effectively. }\end{array}$ \\
\hline Public information & $\begin{array}{l}\text { Institutions should publish information about their activities, including programmes } \\
\text { that are clear, accurate, objective, up-to-date, and readily accessible. }\end{array}$ \\
\hline $\begin{array}{l}\text { Ongoing monitoring } \\
\text { and periodic review of } \\
\text { programmes }\end{array}$ & $\begin{array}{l}\text { Institutions should monitor and periodically review their programmes to ensure that } \\
\text { they achieve the objectives set for them and respond to the needs of students and } \\
\text { society. These reviews should lead to continuous improvement of the programme. }\end{array}$ \\
\hline $\begin{array}{l}\text { Cyclical external quality } \\
\text { assurance }\end{array}$ & $\begin{array}{l}\text { Institutions should undergo external quality assurance in line with the ESG on a } \\
\text { cyclical basis. }\end{array}$ \\
\hline
\end{tabular}




\section{ACBSP Accreditation Council for Business Schools and Programs ${ }^{[6]}$}

Accreditation Council for Business Schools and Programs, formerly known as the Association of Collegiate Business Schools and Programs, is an American organization that provides accreditation services for business programs that focus on teaching and learning. It was established to meet the need for specialized accreditation by colleges and universities that have business schools and programs. The board was established in 1989 to accredit business schools with a focus on teaching and learning. At the time, only 260 of the 2,400 business schools had specialist professional accreditation, all from the Association of Advance Collegiate Schools of Business (ABCBAC). Most of all of the council-accredited schools focused on research, while most others focused on teaching. On April 28, 1988, 150 non-accredited schools met in Kansas City, Missouri, to consider alternatives to accrediting the Business Schools and Programs Accreditation Board for educational-oriented schools.

\section{Accreditation Criteria}

\begin{tabular}{|c|c|}
\hline \multicolumn{2}{|l|}{ Accreditation Standards } \\
\hline Leadership & $\begin{array}{l}\text { The business unit must have systematic leadership processes that promote } \\
\text { performance excellence and continuous improvement. Values and expectations } \\
\text { must be integrated into the business unit's leadership process to enable the business } \\
\text { unit to address its societal responsibilities and community involvement. }\end{array}$ \\
\hline Strategic Planning & $\begin{array}{l}\text { The business unit must have a systematic process for developing a strategic } \\
\text { plan that leads to continuous improvement. The strategic plan must include } \\
\text { implementation goals and progress measures. }\end{array}$ \\
\hline $\begin{array}{l}\text { Student and Stakeholder } \\
\text { Focus }\end{array}$ & $\begin{array}{l}\text { The business unit must have a systematic process to determine the requirements and } \\
\text { expectations of current and future students and other key stakeholders. The process } \\
\text { must measure stakeholder participation and satisfaction and use the results for } \\
\text { continuous improvement. }\end{array}$ \\
\hline $\begin{array}{l}\text { Student Learning } \\
\text { Assessment }\end{array}$ & $\begin{array}{l}\text { The business unit must have a systematic student learning outcomes assessment } \\
\text { process and plan that leads to continuous improvement. Student learning outcomes } \\
\text { must be developed and implemented for each accredited program, and the results } \\
\text { must be communicated to stakeholders. }\end{array}$ \\
\hline \multirow[t]{2}{*}{ Faculty Focus } & $\begin{array}{l}\text { The business unit must have a systematic process to ensure current and qualified } \\
\text { faculty members by: }\end{array}$ \\
\hline & $\begin{array}{l}\text { Fostering teaching excellence, aligning faculty credentials and skillsets with current } \\
\text { and future program objectives, evaluating faculty members based on defined } \\
\text { criteria and objectives, and ensuring faculty development, including scholarly and } \\
\text { professional activity }\end{array}$ \\
\hline Curriculum & $\begin{array}{l}\text { The business unit must have a systematic process to ensure continuous } \\
\text { improvement of curriculum and program delivery. The curriculum must be } \\
\text { comprised of appropriate business and professional content to prepare graduates for } \\
\text { success. }\end{array}$ \\
\hline Business Unit Performance & $\begin{array}{l}\text { The business unit must have a systematic process to identify and track key student } \\
\text { performance measures for the purpose of continuous improvement. The business } \\
\text { unit must ensure adequate resources and services to support its programs. }\end{array}$ \\
\hline
\end{tabular}




\section{The Curacao Accreditation Agency (AAC) ${ }^{[3]}$}

The Curacao Accreditation Agency is an independent and professional accrediting agency for higher education located in Curacao. The Curacao Accreditation Agency is officially recognized by the Ministry of Education, Science, Culture, and Sports of the Curacao government. The purpose of the agency is to promote quality assurance in education and vocational training. It was established to accredit degree programs in universities, universities of applied sciences, colleges and vocational schools (bachelor's, master's, and doctoral study programs), and higher education institutions. The agency conducts procedures for accrediting educational programs in all disciplines (program accreditation) as well as procedures for accreditation of educational institutions.

\section{Accreditation Criteria}

\begin{tabular}{|c|c|}
\hline \multicolumn{2}{|l|}{ Accreditation Standards ${ }^{[32]}$} \\
\hline $\begin{array}{l}\text { Mission, Goals, and } \\
\text { Objectives }\end{array}$ & $\begin{array}{l}\text { The institution's mission statement must clearly and appropriately define its } \\
\text { principal purposes and priorities and influence planning and action within the } \\
\text { institution. The quality assurance system shall be incorporated into the strategy } \\
\text { of the higher education institution (HEI) or other institution within the higher } \\
\text { education sector and efficiently support its development. }\end{array}$ \\
\hline $\begin{array}{l}\text { Governance and } \\
\text { Administration }\end{array}$ & $\begin{array}{l}\text { The governing body must provide effective leadership in the interests of the } \\
\text { institution as a whole and its clients through policy development and processes } \\
\text { for accountability. Senior administrators must lead the activities of the institution } \\
\text { effectively within a clearly defined governance structure. Their activities must be } \\
\text { consistent with high standards of integrity and ethical practice. }\end{array}$ \\
\hline $\begin{array}{l}\text { Management of } \\
\text { Quality Assurance and } \\
\text { Improvement }\end{array}$ & $\begin{array}{l}\text { Institutions should have a policy for quality assurance that is made public and } \\
\text { forms part of their strategic management. Internal participants should develop and } \\
\text { implement this policy through appropriate structures and processes while involving } \\
\text { external participants. Quality assurance processes must involve all institution } \\
\text { sections and be effectively integrated into everyday planning and administrative } \\
\text { processes. }\end{array}$ \\
\hline Learning and Teaching & $\begin{array}{l}\text { The institution must have an effective system for ensuring that all programs meet } \\
\text { high standards of learning and teaching through initial approvals, monitoring } \\
\text { of performance, and provision of institution-wide support services. Standards } \\
\text { of learning must be assessed and verified through appropriate processes and } \\
\text { benchmarked against demanding and relevant external reference points. }\end{array}$ \\
\hline $\begin{array}{l}\text { Student Administration and } \\
\text { Support Services }\end{array}$ & $\begin{array}{l}\text { Student admissions, assessing student performance, and awarding their degrees are } \\
\text { essential components of the student "life cycle." Institutions should consistently } \\
\text { apply predefined and published regulations covering all phases of the "life } \\
\text { cycle."Access policies, admission processes, and criteria must be implemented } \\
\text { consistently and transparently. }\end{array}$ \\
\hline Learning Resources & $\begin{array}{l}\text { For a good higher education experience, institutions provide a range of resources to } \\
\text { assist student learning. These vary from physical resources such as libraries, study } \\
\text { facilities, and IT infrastructure to human support in the form of tutors, counselors, } \\
\text { and other advisers. }\end{array}$ \\
\hline Facilities and Equipment & $\begin{array}{l}\text { Facilities must be designed or adapted to meet the particular requirements for } \\
\text { teaching and learning in the programs offered by the institution and provide a safe } \\
\text { and healthy environment for high-quality education. The use of facilities must be } \\
\text { monitored, and user surveys used to assist in planning for improvement. }\end{array}$ \\
\hline
\end{tabular}




\begin{tabular}{|l|l|}
\hline $\begin{array}{l}\text { Financial Planning and } \\
\text { Management }\end{array}$ & $\begin{array}{l}\text { The resources and infrastructure suit the particular characteristics of the HE } \\
\text { institution, including in terms of teaching methods (e.g., distance learning) and to } \\
\text { meet the needs of the institution's activities, including in terms of organization, } \\
\text { planning, and strategy of allocation. }\end{array}$ \\
\hline Employment Processes & $\begin{array}{l}\text { Teaching and other staff must have the qualifications and experience required for } \\
\text { the effective exercise of their responsibilities. Professional development strategies } \\
\text { must be followed to ensure continuous improvement in the expertise of teaching } \\
\text { and other staff. Performance of all teaching and other staff must be periodically } \\
\text { evaluated, with outstanding performance recognized and support provided for } \\
\text { improvement where required. Effective, fair, and transparent processes must be } \\
\text { available for the resolution of conflicts and disputes involving teaching or other } \\
\text { staff. }\end{array}$ \\
\hline Research & $\begin{array}{l}\text { The institution has a plausible research portfolio, which is embedded in its overall } \\
\text { strategy. There are systematic linkages between research activities, teaching, and } \\
\text { knowledge transfer. The institution identifies new fields of research and considers } \\
\text { the further development of its research strategy. It takes up scientific trends as well } \\
\text { as research demands in its environment. }\end{array}$ \\
\hline $\begin{array}{l}\text { Relationships with the } \\
\text { Community }\end{array}$ & $\begin{array}{l}\text { Contributing to the community must be recognized as an essential institutional } \\
\text { responsibility. Facilities and services must be made available to assist with } \\
\text { community developments. Teaching and other staff must be encouraged to be } \\
\text { involved in the community and information about the institution and its activities } \\
\text { made known to the community through public media and other appropriate } \\
\text { mechanisms. }\end{array}$ \\
\hline
\end{tabular}

\section{Accrediting Commission for Community and Junior Colleges (ACCJC) ${ }^{[7]}$}

Accrediting Commission for Community and Junior Colleges (ACCJC) is one of seven regional accrediting organizations in the United States. ACCJC accredits private and public colleges that provide students with two-year educational programs and associate degree-awarding. The committee's scope of work includes colleges in California, Hawaii, and US Pacific regions and reserves.

\section{Accreditation Criteria}

\begin{tabular}{|l|l|}
\hline Accreditation Standards & $\begin{array}{l}\text { The institution is authorized or licensed to operate as a post-secondary educational } \\
\text { institution and award degrees by an appropriate governmental organization or } \\
\text { agency as required by each of the jurisdictions or regions in which it operates. }\end{array}$ \\
\hline Authority & The institution is operational, with students actively pursuing its degree programs. \\
\hline Operational Status & $\begin{array}{l}\text { A substantial portion of the institution's educational offerings are programs that } \\
\text { lead to degrees, and a significant proportion of its students are enrolled in them. At } \\
\text { least one-degree program must be of two academic years in length. }\end{array}$ \\
\hline Chief Executive Officer & $\begin{array}{l}\text { The institution has a chief executive officer appointed by the governing board, } \\
\text { whose full-time responsibility is to the institution, and who possesses the requisite } \\
\text { authority to administer board policies. }\end{array}$ \\
\hline Financial Accountability & $\begin{array}{l}\text { The institution annually undergoes and makes an external financial audit available } \\
\text { by a certified public accountant or an audit by an appropriate public agency. }\end{array}$ \\
\hline Mission & $\begin{array}{l}\text { The institution's educational mission is clearly defined, adopted, and published } \\
\text { by its governing board consistent with its legal authorization and is appropriate } \\
\text { to a degree-granting institution of higher education and the constituency it seeks } \\
\text { to serve. The mission statement defines an institutional commitment to student } \\
\text { learning and achievement. }\end{array}$ \\
\hline
\end{tabular}




\begin{tabular}{|c|c|}
\hline Governing Board & $\begin{array}{l}\text { The institution has a functioning governing board responsible for the institution's } \\
\text { academic quality, institutional integrity, and financial stability and for ensuring } \\
\text { that the institution's mission is achieved. This board is ultimately responsible } \\
\text { for ensuring that the institution's financial resources are used to provide a sound } \\
\text { educational program. Its membership is sufficient in size and composition to fulfill } \\
\text { all board responsibilities }\end{array}$ \\
\hline Administrative Capacity & $\begin{array}{l}\text { The institution has sufficient staff, with appropriate preparation and experience to } \\
\text { provide the administrative services necessary to support its mission and purpose }\end{array}$ \\
\hline Educational Programs & $\begin{array}{l}\text { The institution's principal degree programs are congruent with its mission, are } \\
\text { based on recognized higher education field(s) of study, are of sufficient content } \\
\text { and length, are conducted at levels of quality and rigor appropriate to the degrees } \\
\text { offered }\end{array}$ \\
\hline Academic Credit & $\begin{array}{l}\text { The institution awards academic credits based on generally accepted practices for } \\
\text { degree-granting institutions of higher education and in accordance with statutory or } \\
\text { system regulatory requirements. }\end{array}$ \\
\hline $\begin{array}{l}\text { Student Learning and } \\
\text { Student Achievement }\end{array}$ & $\begin{array}{l}\text { The institution defines standards for student achievement and assesses its } \\
\text { performance against those standards. The institution publishes for each program } \\
\text { the program's expected student learning and any program-specific achievement } \\
\text { outcomes. }\end{array}$ \\
\hline General Education & $\begin{array}{l}\text { The institution defines and incorporates a substantial component of general } \\
\text { education into all of its degree programs designed to ensure breadth of knowledge } \\
\text { and promote intellectual inquiry. The available education component includes an } \\
\text { introduction to some of the significant areas of knowledge }\end{array}$ \\
\hline Academic Freedom & $\begin{array}{l}\text { The institution's faculty and students are free to examine and test all knowledge } \\
\text { appropriate to their discipline or area of major study as judged by the academic/ } \\
\text { educational community in general. Regardless of institutional affiliation or } \\
\text { sponsorship, the institution maintains an atmosphere in which intellectual freedom } \\
\text { and independence exist. }\end{array}$ \\
\hline Faculty & $\begin{array}{l}\text { The institution has a sufficient number of qualified faculty, including full-time } \\
\text { faculty and part-time and adjunct faculty, to achieve the institutional mission and } \\
\text { purposes. The number is sufficient in size and experience to support all of the } \\
\text { institution's educational programs. }\end{array}$ \\
\hline Student Support Services & $\begin{array}{l}\text { The institution provides for all of its student's appropriate student support services } \\
\text { that foster student learning and development within the context of the institutional } \\
\text { mission. }\end{array}$ \\
\hline Admissions & $\begin{array}{l}\text { The institution has adopted and adheres to admission policies consistent with its } \\
\text { mission that specify students' qualifications appropriate for its programs. }\end{array}$ \\
\hline $\begin{array}{l}\text { Information and Learning } \\
\text { Support Services }\end{array}$ & $\begin{array}{l}\text { Through ownership or contractual agreement, the institution provides specific long- } \\
\text { term access to sufficient information and learning support services adequate for } \\
\text { its mission and instructional programs in whatever format whenever and wherever } \\
\text { they are offered. }\end{array}$ \\
\hline Financial Resources & $\begin{array}{l}\text { The institution documents a funding base, financial resources, and plans for } \\
\text { financial development adequate to support student learning programs and services, } \\
\text { improve institutional effectiveness, and assure financial stability. }\end{array}$ \\
\hline $\begin{array}{l}\text { Institutional Planning and } \\
\text { Evaluation }\end{array}$ & $\begin{array}{l}\text { The institution systematically evaluates and makes public how well and in what } \\
\text { ways it is accomplishing its purposes, including assessment of student learning } \\
\text { outcomes. The institution provides evidence of planning to improve institutional } \\
\text { structures and processes, student achievement of educational goals, and student } \\
\text { learning. }\end{array}$ \\
\hline $\begin{array}{l}\text { Integrity in Communication } \\
\text { with the Public }\end{array}$ & $\begin{array}{l}\text { The institution provides a print or electronic catalog for its constituencies with } \\
\text { precise, accurate, and current information concerning all policies and protocols } \\
\text { related to students and his/her study. }\end{array}$ \\
\hline
\end{tabular}




\section{The New England Commission of Higher Education - NECHE ${ }^{[30]}$}

The New England Commission of Higher Education is the regional accrediting agency for colleges and universities in six New England states Connecticut, Maine, Massachusetts, New Hampshire, Rhode Island, and Vermont. The committee consists of faculty members and administrators from affiliated institutions, and general members. The US Secretary of Education recognizes the committee as the authoritative authority on the quality of education for the institutions accrediting it. The committee is also recognized by the Council for Higher Education Accreditation (CHEA), assuring that its standards and processes align with the quality, improvement, and accountability expectations established by CHEA.

\section{Accreditation Criteria}

\begin{tabular}{|c|c|}
\hline \multicolumn{2}{|l|}{ Accreditation Standards ${ }^{[36]}$} \\
\hline Mission and Purposes & $\begin{array}{l}\text { The institution's mission and purposes are appropriate to higher education, } \\
\text { consistent with its charter or other operating authority, and implemented in a } \\
\text { manner that complies with the Standards of the New England Commission of } \\
\text { Higher Education. The institution's mission gives direction to its activities and } \\
\text { provides a basis for assessing and enhancing the institution's effectiveness. }\end{array}$ \\
\hline Planning and Evaluation & $\begin{array}{l}\text { The institution undertakes planning and evaluation to accomplish and improve the } \\
\text { achievement of its mission and purposes. It identifies its planning and evaluation } \\
\text { priorities and pursues them effectively. The institution demonstrates its success in } \\
\text { strategic, academic, financial, and other resource planning and the evaluation of } \\
\text { its educational effectiveness. }\end{array}$ \\
\hline Organization and Governance & $\begin{array}{l}\text { The institution has a system of governance that facilitates the accomplishment } \\
\text { of its mission and purposes and supports institutional effectiveness and integrity. } \\
\text { Through its organizational design and governance structure, the institution } \\
\text { creates and sustains an environment that encourages teaching, learning, service, } \\
\text { scholarship, and appropriate research and creative activity. }\end{array}$ \\
\hline The Academic Program & $\begin{array}{l}\text { The institution's academic programs are consistent with and serve to fulfill its } \\
\text { mission and purposes. The institution works systematically and effectively to } \\
\text { plan, provide, oversee, evaluate, improve, and assure its academic programs' } \\
\text { academic quality and integrity and the credits and degrees awarded. }\end{array}$ \\
\hline Students & $\begin{array}{l}\text { Consistent with its mission, the institution sets and achieves realistic goals to } \\
\text { enroll students who are broadly representative of the institution's population. } \\
\text { The institution addresses its own goals for the achievement of diversity, equity, } \\
\text { and inclusion among its students and provides a safe environment that fosters the } \\
\text { intellectual and personal development of its students. }\end{array}$ \\
\hline $\begin{array}{l}\text { Teaching, Learning, and } \\
\text { Scholarship }\end{array}$ & $\begin{array}{l}\text { The institution supports teaching and learning through a well-qualified faculty } \\
\text { and academic staff, who, in structures and processes appropriate to the institution, } \\
\text { collectively ensure the quality of instruction and support for student learning. } \\
\text { Scholarship, research, and creative activities receive support relevant to the } \\
\text { institution's mission. }\end{array}$ \\
\hline Institutional Resources & $\begin{array}{l}\text { The institution has sufficient human, financial, information, physical, and } \\
\text { technological resources and capacity to support its mission. Through periodic } \\
\text { evaluation, the institution demonstrates that its resources are sufficient to sustain } \\
\text { its educational program's quality and support institutional improvement now and } \\
\text { in the foreseeable future. }\end{array}$ \\
\hline
\end{tabular}




\begin{tabular}{|l|l|}
\hline Educational Effectiveness & $\begin{array}{l}\text { The institution demonstrates its effectiveness by ensuring satisfactory levels } \\
\text { of student achievement on mission-appropriate student outcomes. Based on } \\
\text { verifiable information, the institution understands what its students have gained } \\
\text { due to their education and has useful evidence about the success of its recent } \\
\text { graduates. }\end{array}$ \\
\hline $\begin{array}{l}\text { Integrity, Transparency, and } \\
\text { Public Disclosure }\end{array}$ & $\begin{array}{l}\text { The institution subscribes to and advocates high ethical standards in managing } \\
\text { its affairs and in its dealings with students, prospective students, faculty, staff, } \\
\text { its governing board, external agencies and organizations, and the general public. } \\
\text { Through its policies and practices, the institution endeavors to exemplify the } \\
\text { values it articulates in its mission and related statements. }\end{array}$ \\
\hline
\end{tabular}

\section{National Assessment and Accreditation Board (NAAC)}

The National Assessment and Accreditation Board (NAAC) is a government organization that evaluates and accredits higher education institutions in India. It is an independent body funded by the University Grants Commission and based in Bangalore. The council was established in 1994 in response to the recommendations of the National Policy on Education (1986). This policy was aimed at "addressing issues of deteriorating quality of education", and the work program developed strategic policy plans including the establishment of an independent national accreditation body.

\section{Accreditation Criteria}

\begin{tabular}{|c|c|}
\hline \multicolumn{2}{|l|}{ Accreditation Standards } \\
\hline Curricular Aspects & $\begin{array}{l}\text { The institution ensures effective curriculum delivery through a well-planned and } \\
\text { documented process. Teachers of the Institution participate in the following activities } \\
\text { related to curriculum development and assessment of the affiliating university and/are } \\
\text { represented on the following academic bodies during the last five years. }\end{array}$ \\
\hline $\begin{array}{l}\text { Teaching-Learning and } \\
\text { Evaluation }\end{array}$ & $\begin{array}{l}\text { The institution assesses the learning levels of the students and organizes special } \\
\text { Programmes for advanced learners and slow learners. Student-centric methods, such } \\
\text { as experiential learning, participative learning, and problem-solving methodologies } \\
\text { are used for enhancing learning experiences }\end{array}$ \\
\hline $\begin{array}{l}\text { Research, Innovations, } \\
\text { and Extension }\end{array}$ & $\begin{array}{l}\text { Grants received from government and non-governmental agencies for research } \\
\text { projects, endowments, Chairs in the institution during the last five years (INR in } \\
\text { Lakhs). Percentage of teachers recognized as research guides (latest completed } \\
\text { academic year). }\end{array}$ \\
\hline $\begin{array}{l}\text { Infrastructure and } \\
\text { Learning Resources }\end{array}$ & $\begin{array}{l}\text { The institution has adequate infrastructure and physical facilities for teaching- } \\
\text { learning. Viz., classrooms, laboratories, computing equipment, etc. The institution has } \\
\text { adequate facilities for cultural activities, sports, games (indoor, outdoor), gymnasium, } \\
\text { yoga centre, etc. Percentage of classrooms and seminar halls with ICT- enabled } \\
\text { facilities such as smart class, LMS, etc. }\end{array}$ \\
\hline $\begin{array}{l}\text { Student Support and } \\
\text { Progression }\end{array}$ & $\begin{array}{l}\text { The average percentage of students benefited by scholarships and freeships provided } \\
\text { by the government during the last five years. The average percentage of students } \\
\text { benefitted by scholarships, freeships, etc., supplied by the institution / non- } \\
\text { government agencies during the previous five years. Capacity building and skills } \\
\text { enhancement initiatives taken by the institution include the following. }\end{array}$ \\
\hline $\begin{array}{l}\text { Governance, Leadership, } \\
\text { and Management }\end{array}$ & $\begin{array}{l}\text { The institution's governance is reflective of and in tune with the vision and mission of } \\
\text { the institution. Effective leadership is visible in various institutional practices such as } \\
\text { decentralization and participative management. }\end{array}$ \\
\hline $\begin{array}{l}\text { Institutional Values and } \\
\text { Best Practices }\end{array}$ & $\begin{array}{l}\text { Measures initiated by the institution for the promotion of gender equity during the } \\
\text { last five years. The institution has facilities for alternate sources of energy and energy } \\
\text { conservation measures. }\end{array}$ \\
\hline
\end{tabular}




\section{Barbaros Accreditation Board, BAC}

The Barbaros Accreditation Board is an academic accrediting body located in Barbaros.

\section{Accreditation Criteria}

\begin{tabular}{|l|l|}
\hline Accreditation Standards & $\begin{array}{l}\text { The institution's mission and objectives are appropriate to post-secondary or tertiary } \\
\text { education and consistent with the policies and practices that guide its operations. } \\
\text { The programme maintains a clear and publicly stated philosophy and specific } \\
\text { educational objectives that are consistent with the provider's mission and objectives } \\
\text { and are appropriate to post-secondary or tertiary education and training. }\end{array}$ \\
\hline $\begin{array}{l}\text { Governance and } \\
\text { Administration }\end{array}$ & $\begin{array}{l}\text { The institution's system of governance ensures ethical decision-making and efficient } \\
\text { provision of human, physical and financial resources to accomplish its educational } \\
\text { and other purposes effectively. Appropriate structures support the programme for } \\
\text { effective policy-making and implementation and the necessary human, physical and } \\
\text { financial resources to achieve its objectives and educational outcomes. }\end{array}$ \\
\hline Teaching and Learning & $\begin{array}{l}\text { The institution provides evidence of student learning outcomes and faculty } \\
\text { effectiveness in achieving its educational objectives and demonstrates the } \\
\text { capability to continue to do so. The programme successfully achieves student } \\
\text { learning outcomes and faculty effectiveness that demonstrates that it is fulfilling its } \\
\text { educational purposes and can continue to do so. }\end{array}$ \\
\hline Curriculum Effectiveness & $\begin{array}{l}\text { The institution monitors, reviews, and improves its Quality Management Systems } \\
\text { through effective planning and evaluation, sustained effort, and commitment to } \\
\text { quality. The programme is effectively designed to ensure relevance and to maintain } \\
\text { certification requirements that conform to accepted standards in that profession or } \\
\text { field of study. }\end{array}$ \\
\hline Quality Enhancement & $\begin{array}{l}\text { The programme maintains a systematic approach to assessing educational quality in } \\
\text { order to improve educational and other outcomes. }\end{array}$ \\
\hline Readiness for Change & $\begin{array}{l}\text { The institution's human, physical and financial resources are strategically allocated } \\
\text { and employed to respond to the social and economic needs of a rapidly changing } \\
\text { global society. }\end{array}$ \\
\hline
\end{tabular}

\section{AHPGS Accreditation Agency in Health and Social Sciences}

The Accreditation Agency in Health and Social Sciences (AHPGS) is a multidisciplinary and interdisciplinary organization focusing on Accreditation of Bachelor's / Master's programs and internal quality assurance systems in universities and other higher education institutions. The agency works with particular competence in the fields of health and social sciences and other neighboring and related disciplines.

\section{Accreditation Criteria}

\begin{tabular}{|l|l|}
\hline Accreditation Standards \\
\hline Aims and Implementation & $\begin{array}{l}\text { The study program pursues specific qualification objectives. These objectives } \\
\text { cover professional and extraprofessional/interdisciplinary aspects and mainly refer } \\
\text { to the domain of academic competences, competencies necessary for qualified } \\
\text { employment, social commitment, and personal development skills. }\end{array}$ \\
\hline
\end{tabular}




\begin{tabular}{|l|l|}
\hline $\begin{array}{l}\text { Structure of the Study } \\
\text { Program }\end{array}$ & $\begin{array}{l}\text { The study program aims to provide students with specialized and interdisciplinary } \\
\text { knowledge and professional, methodological, and general competencies. }\end{array}$ \\
\hline Admission and Feasibility & $\begin{array}{l}\text { The admission requirements and, if applied, student selection procedures are } \\
\text { specified. They correspond to the standards of the study program. }\end{array}$ \\
\hline $\begin{array}{l}\text { Examination System and } \\
\text { Transparency }\end{array}$ & $\begin{array}{l}\text { Examinations serve to determine whether the envisaged qualification objectives } \\
\text { have been achieved. These examinations are focused on students' knowledge } \\
\text { and competencies. The requirements for student's performance in examinations } \\
\text { are regulated and published. The frequency of examinations, as well as their } \\
\text { organization, is appropriate. }\end{array}$ \\
\hline $\begin{array}{l}\text { Teaching Staff and } \\
\text { Material Equipment }\end{array}$ & $\begin{array}{l}\text { Professionalism and a sufficient number of human resources assure the successful } \\
\text { implementation of the study program. Qualifications of the teaching personnel } \\
\text { correspond to the requirements of the study program. Recruitment and appointment } \\
\text { on teaching positions are implemented in a fair and transparent manner. } \\
\text { Interdisciplinary links to other study programs are taken into consideration. }\end{array}$ \\
\hline Quality Assurance & $\begin{array}{l}\text { The university has developed and documented a concept of quality assurance in the } \\
\text { education process and teaching and research, which is publicly available and serves } \\
\text { as the basis for the quality-oriented development and implementation of the study } \\
\text { program. }\end{array}$ \\
\hline $\begin{array}{l}\text { Gender Equality and Equal } \\
\text { Opportunities }\end{array}$ & $\begin{array}{l}\text { The university's actions on providing gender equality and promotion of equal } \\
\text { opportunities for students with particular living circumstances are implemented } \\
\text { transparently. }\end{array}$ \\
\hline
\end{tabular}

\section{ASIC Accreditation Service for International Colleges}

The Accreditation Service for International Schools, Colleges, and Universities is an independent agency for assessing international educational standards-based in the United Kingdom. The accreditation service for international schools, colleges, and universities is designated by the UK Border Agency of the UK government to inspect colleges seeking to apply for sponsorship licenses from the UK Border Agency. It is one of the accreditation bodies that has been recognized since 2007 by the UK Border Agency, which has now replaced it. According to its website, the accreditation service for international schools, colleges and universities has accredited 148 colleges and universities in the United Kingdom, and about 80 institutions worldwide, of which 15 are based in the United States.

\section{Accreditation Criteria}

\begin{tabular}{|l|l|}
\hline Accreditation Standards \\
\hline $\begin{array}{l}\text { Premises, and Health and } \\
\text { Safety }\end{array}$ & $\begin{array}{l}\text { Floor plan of each site being inspected, showing classrooms and other teaching } \\
\text { facilities, offices, toilets, student study areas, refreshment areas, residential areas } \\
\text { and emergency exits. List of all teaching rooms offering capacities and any } \\
\text { specific teaching resources. }\end{array}$ \\
\hline $\begin{array}{l}\text { Governance, Management } \\
\text { and Staff Resources }\end{array}$ & $\begin{array}{l}\text { An opportunity should be made for the Inspectors to meet the Institution's } \\
\text { Owner(s), Directors, and a member of the Governing Body if applicable. The } \\
\text { governance arrangements, staff numbers and structure, and vision for the } \\
\text { institution are appropriate for the scale and nature of the operation. Local/ } \\
\text { legal employment requirements are met/good practice exists in terms of equal } \\
\text { opportunities, disciplinary and grievance procedures, Employer's Liability } \\
\text { insurance, Public Liability insurance, staff workloads. Courses/programmes and/ } \\
\text { or academic subject areas are managed by appropriately qualified and experienced } \\
\text { staff. }\end{array}$ \\
\hline
\end{tabular}




\begin{tabular}{|c|c|}
\hline $\begin{array}{l}\text { Learning, Teaching and } \\
\text { Research Activity }\end{array}$ & $\begin{array}{l}\text { The general approach to students' learning is that they should be guided and } \\
\text { encouraged to take responsibility for their own learning. This helps ensure that } \\
\text { they can build on the knowledge and experience gained on their courses in taking } \\
\text { higher-level courses and/or developing their careers. Pre-enrolment, students } \\
\text { receive details of entry requirements/other criteria, fee charges and refund policy, } \\
\text { and the personal documentation which has to be produced in order to complete } \\
\text { enrolment. The academic staff has an appropriate level of subject knowledge } \\
\text { (generally at least a first degree or equivalent professional qualification and at } \\
\text { an academic equivalent to the level of the course(s) being taught) and pedagogic } \\
\text { skills as evidenced (normally) by formal qualifications. }\end{array}$ \\
\hline $\begin{array}{l}\text { Quality Assurance and } \\
\text { Enhancement }\end{array}$ & $\begin{array}{l}\text { Course/programme review is a crucial procedure whereby the institution reviews } \\
\text { the delivery of its courses and the student's success as part of a process of } \\
\text { continual improvement and of ensuring the ongoing relevance of the curriculum. }\end{array}$ \\
\hline Student Welfare & $\begin{array}{l}\text { Institutions in many countries now seek to recruit international students from other } \\
\text { countries. Such students often need support in addition to that provided for home } \\
\text { students. Students receive advice/information and assistance concerningliving } \\
\text { costs, police registration, medical treatment, banking, and travel cards. }\end{array}$ \\
\hline Awards and Qualifications & $\begin{array}{l}\text { An external course/programme is an approved awarding body that provides the } \\
\text { curriculum and assessment schedule, including approved universities, professional } \\
\text { bodies, and other recognized awarding bodies. An internal course/programme } \\
\text { is one that has been totally devised by the institution and may be validated by a } \\
\text { university or another approved awarding body. }\end{array}$ \\
\hline $\begin{array}{l}\text { Marketing and } \\
\text { Recruitment of Students }\end{array}$ & $\begin{array}{l}\text { All staff and education representatives/agents adopt an honest, ethical approach in } \\
\text { the institution's marketing and its courses/programmes and in the recruitment of } \\
\text { students. An appropriate infrastructure exists for dealing with student inquiries. }\end{array}$ \\
\hline $\begin{array}{l}\text { Systems Management } \\
\text { and Compliance with } \\
\text { Immigration Regulations }\end{array}$ & $\begin{array}{l}\text { It is expected that all of its accredited institutions have written procedures for all } \\
\text { of their policies and actions. The person with responsibility for each procedure can } \\
\text { explain it to the Inspectors. This has the added advantage that if staff undertaking } \\
\text { particular roles leave or are unavailable at short notice, other staff assuming these } \\
\text { roles will know exactly what is expected of them. This applies in particular to } \\
\text { procedures for the recruitment, enrolment, and monitoring of attendance and } \\
\text { academic progress of the home and international students. }\end{array}$ \\
\hline
\end{tabular}

\section{ISO 21001 and its applications}

During COVID-19, many schools and higher education institutes have initiated innovative, technologybased learning models for effective and continued delivery of education.

Education not be business as usual. Based on guidance from the World Health Organization- UNESCO, UNICEF, World Bank and the World Food Programme have released a Framework for Reopening Schools, which gives prominent attention to not only health and protection measures but also to 'standardizing' our educational practices.

Schools and higher education will have to focus more on practices that compensate for lost instructional time, strengthen pedagogy and build on hybrid learning models such as integrated approaches in remote and distance education.

We all know that Education transforms lives- not only in one generation but across generations. This sector is the most important of all sectors. Whether a school, a college, university, coaching institute or a training institute, everybody is contributing in the transformation of human beings. To structure this sector well, It's extremely imp to adopt an attitude of systems, processes, innovation and excellence. For 
us to be globally competitive in manufacturing and service industries, it has to depend upon educational systems to provide competent manpower now and in future.

The higher educational scenario in most countries is a curious mix of modernism and tradition. Internationally comparable IB schools and colleges and then we have well-established, reputed and traditional institutions. The other organizations of national \& international repute co-exist with average and below average institutions. There is no common framework which can evaluate the performance of these institutions and also verify the degree to which they meet the requirements of learners and other stakeholders.

A standard which not only talks about quality but also other compliances like - health \& safety, risk management, information security, sustainable practices through minimizing impact on environment, food safety, facility management, anti-bribery and business continuity.

The ISO 21001 standard dedicated to the management system for educational institutions was published as an international standard by the International Organization for Standardization and was issued in early 2018. Its purpose is to provide a common management tool for institutions that offer educational products and services capable of meeting the learner's requirements and other requirements and needs of customers. The ISO 21001 standard is considered an independent standard as it is based on the ISO 9001 standard without being directly affected by it. It is in line with the rest of the International Organization for Standardization standards in terms of its structure and structure. The ISO 21001 standard focuses on the specific interaction between an educational institution, the learner, customers, and other relevant interested parties and defines the requirements for the educational institution management system. All requirements of the ISO 21001 standard are general and aim to be applicable to all educational institutions that provide, participate and facilitate the building of knowledge for learners through teaching, training, or research, regardless of type, size, product, and service provided. Therefore, the standard applies to the management system of any organization that uses an approach to providing, sharing, and imparting knowledge.

The ISO 21001 standard pays special attention to the following points:

1. Focus on learners and other beneficiaries: The primary focus of the educational test administration system is to meet the requirements of the learner and other beneficiaries and exceed their expectations.

2. Wise and aware leadership: Wise leadership is the involvement of all learners and other beneficiaries in creating, writing, and implementing the organization's mission, vision, and goals.

3. Engaging People: It is imperative for an organization that all of the individuals involved are qualified, empowered, and engaged in delivering value.

4. Process approach: consistent and predictable results are achieved more effectively and efficiently when activities are understood and managed as interconnected processes that function as a coherent system, including inputs and outputs.

5. Improvement: Successful organizations have an ongoing focus on improvement.

6. Evidence-based decisions: Decisions and approaches based on analyzing and evaluating data and information are likely to produce the desired results.

7. Relationship Management: To achieve continued success, organizations manage their relationships with interested parties, such as service providers. 
8. Social Responsibility: Socially responsible organizations are sustainable and ensure long-term success.

9. Accessibility and Equity: Successful organizations are inclusive, flexible, transparent, and accountable to meet learners' individual and specific needs, interests, abilities, and backgrounds.

10. Ethical behavior in education: Ethical behavior relates to an organization's ability to create a professional, ethical environment in which all interested parties are treated fairly, avoid conflicts of interest, and conduct activities to benefit society.

11. Data Security and Protection: The organization creates an environment in which all interested parties can interact with the educational institution with complete confidence that they maintain control over the use of their own data and that the educational institution will handle their data with care and confidentiality.

\section{Broad Features}

\begin{tabular}{|c|c|}
\hline \multicolumn{2}{|r|}{ Standard Requirements ${ }^{[24]}$} \\
\hline $\begin{array}{l}\text { Understanding the } \\
\text { organization and its context }\end{array}$ & $\begin{array}{l}\text { The organization shall determine external and internal issues relevant to its } \\
\text { purpose, its social responsibility, and its strategic direction, which affect its ability } \\
\text { to achieve the intended outcomes of its EOMS. The organization shall monitor } \\
\text { and review information about these external and internal issues. } \\
\text { 1. Understanding the organization and its context } \\
\text { 2. Understanding the needs and expectations of interested parties } \\
\text { 3. Determining the scope of the management system for educational } \\
\text { organizations } \\
\text { 4. Management system for educational organizations (EOMS) }\end{array}$ \\
\hline Leadership & $\begin{array}{l}\text { Top management shall demonstrate leadership and commitment concerning the } \\
\text { EOMS by being accountable for the effectiveness of the EOMS, ensuring that } \\
\text { the educational organization policy and educational organization objectives } \\
\text { are established and are compatible with the context and strategic direction of } \\
\text { the organization, ensuring the integration of the EOMS requirements into the } \\
\text { organization's business processes, and promoting the use of the process approach } \\
\text { and risk-based thinking. } \\
\text { 1. Leadership and commitment } \\
\text { 2. Policy } \\
\text { 3. Organizational roles, responsibilities, and authorities }\end{array}$ \\
\hline $\begin{array}{l}\text { Planing, Actions to address } \\
\text { risks and opportunities }\end{array}$ & $\begin{array}{l}\text { The organization shall determine the risks and opportunities that need to } \\
\text { be addressed to a) give assurance that the EOMS can achieve its intended } \\
\text { outcome(s), enhance desirable effects, prevent, mitigate or reduce undesired } \\
\text { effects, and achieve continual improvement. } \\
\text { 1. Actions to address risks and opportunities } \\
\text { 2. Educational organization objectives and planning to achieve them } \\
\text { 3. Planning of changes }\end{array}$ \\
\hline
\end{tabular}




\begin{tabular}{|c|c|}
\hline Support & $\begin{array}{l}\text { 1. Resources } \\
\text { 2. Competence } \\
\text { 3. Awareness } \\
\text { 4. Communication } \\
\text { 5. Documented information }\end{array}$ \\
\hline Resources & $\begin{array}{l}\text { The organization shall determine and provide the resources needed for the } \\
\text { establishment, implementation, maintenance, and continual improvement of the } \\
\text { EOMS so that they sustainably enhance learners and staff. }\end{array}$ \\
\hline Competence & $\begin{array}{l}\text { The organization shall determine the necessary competence of person(s) doing } \\
\text { work under its control that affects its educational organization's performance. }\end{array}$ \\
\hline Awareness & $\begin{array}{l}\text { The organization shall ensure that relevant persons doing work under the } \\
\text { organization's control shall be aware of the educational organization policy } \\
\text { and strategy, and relevant EOMS objectives, and their contribution to the } \\
\text { effectiveness of the EOMS, including the benefits of improved educational } \\
\text { organization performance; }\end{array}$ \\
\hline Communication & $\begin{array}{l}\text { The organization shall determine the internal and external communications } \\
\text { relevant to the EOMS. }\end{array}$ \\
\hline Operation & $\begin{array}{l}\text { The organization shall plan, implement and control the processes needed to meet } \\
\text { requirements for the provision of educational products and services. } \\
\text { 1. Operational planning and control } \\
\text { 2. Requirements for the educational products and services } \\
\text { 3. Design and development of the educational products and services } \\
\text { 4. Control of externally provided processes, products, and services } \\
\text { 5. Delivery of the educational products and services } \\
\text { 6. Release of the educational products and services } \\
\text { 7. Control of the nonconforming educational outputs }\end{array}$ \\
\hline $\begin{array}{l}\text { Evaluation: Monitoring, } \\
\text { measurement, analysis, and } \\
\text { evaluation }\end{array}$ & $\begin{array}{l}\text { The organization shall determine what needs to be monitored and measured, the } \\
\text { methods for monitoring, measurement, analysis, and evaluation, as applicable, to } \\
\text { ensure valid outcomes, the acceptance criteria to be used, when the monitoring } \\
\text { and measuring shall be performed, and when the results from monitoring and } \\
\text { measurement shall be analyzed and evaluated. } \\
\text { 1. Monitoring, measurement, analysis, and evaluation } \\
\text { 2. Internal audit } \\
\text { 3. Management review }\end{array}$ \\
\hline $\begin{array}{l}\text { Satisfaction of learners, other } \\
\text { beneficiaries, and staff }\end{array}$ & $\begin{array}{l}\text { The organization shall monitor the satisfaction of learners, other beneficiaries, } \\
\text { and staff, as well as their perceptions of the degree to which their needs and } \\
\text { expectations have been fulfilled. The organization shall determine the methods } \\
\text { for obtaining, monitoring and reviewing, this information. }\end{array}$ \\
\hline
\end{tabular}




\begin{tabular}{|l|l|}
\hline Continual improvement & $\begin{array}{l}\text { The organization shall continually improve the suitability, adequacy, and } \\
\text { effectiveness of the EOMS, taking into account relevant research and best } \\
\text { practices. The organization shall consider the results of analysis and evaluation } \\
\text { and the outputs from management review to determine if some needs or } \\
\text { opportunities shall be addressed as part of continual improvement. } \\
\text { 1. Nonconformity and corrective action } \\
\text { 2. Continual improvement } \\
\text { 3. Opportunities for improvement }\end{array}$ \\
\hline $\begin{array}{l}\text { The organization should apply its social patterns and social relations to society. } \\
\text { Possible actions include: raising awareness and building competence for social } \\
\text { responsibility, including in the organization's strategy a reference to how it } \\
\text { intends to apply social responsibility, adopting written codes of conduct or ethics } \\
\text { that specify the organization's commitment to social responsibility by translating } \\
\text { the principles and values into statements on appropriate behaviour, ensuring } \\
\text { established management practices reflect and address the organization's social } \\
\text { responsibility, identifying how the principles of social responsibility and the } \\
\text { core subjects and issues apply to the various parts of the organization, taking } \\
\text { account of social responsibility when conducting operations for the organization, } \\
\text { incorporating social responsibility into organizational functions and processes, } \\
\text { such as purchasing and investment practices, human resources management. }\end{array}$ \\
\hline
\end{tabular}

Additional guidance provided in the ISO 2100:2018 standard:-

$\square$ Annex A specifies additional requirements for early childhood education for organizations that provide this service.

$\square$ Annex B outlines the principles for an EOMS.

$\square$ Annex $\mathbf{C}$ provides a classification of interested parties.

$\square$ Annex $\mathbf{D}$ provides guidelines for communication with interested parties.

A Annex E provides guidance on processes, measures and tools in educational organizations.

$\square$ Annex $\mathbf{F}$ gives an example of mapping to regional standards.

Annex $G$ outlines health and safety considerations for educational organizations

\section{Approaches and comparisons between quality bodies, accreditation and the ISO 21001 standard}

By analyzing the standards of the accreditation mentioned above bodies and comparing them with the standards and items required to achieve the ISO 21001 certification, the following points can be identified:

$\square$ All quality bodies and agencies in accordance with the ISO 21001 standard share their focus on the student (as a beneficiary of the educational process), and this includes directly the graduate and alumni, who are the direct product that benefits from the educational outcomes. Thus, All quality bodies in accordance with ISO 21001 standard, focus on student centrality as an essential, main and pivotal part of the educational process.

$\square$ All quality bodies in accordance with the ISO 21001 standard focus on the appropriate faculty and selecting faculty members who are sufficiently qualified to provide educational products. These provisions and standards related to the teaching staff also focus and include the transparent 
recruitment/ employment policy in the educational institution, so that this policy must be fair, equitable, and impartial against any individual, race, gender, color, or any other criteria.

The largest part of the quality bodies in accordance with ISO 21001 standard, focus on the information security standard and provide a specific system through which learners' and other interested parties' data is protected and archived in paper and electronic form in a way that guarantees the integrity of the data in the event of any emergency or catastrophic situation.

$\square$ One of the most important standards that the quality bodies focus on, in accordance with ISO 21001 standard, is the publication of public information related to educational programs, registration, registration fees, study/ course duration, examination dates, size and duration of educational programs, transfer of registration, mechanism and methodology for student graduation from the program.

$\square$ Most important quality bodies focus on the need for a higher education management system in the educational institution that is fully responsible for the management of the institution and encourages the development of the institution, support and understanding of its personnel and encourage them to develop work in the institution and this protocol is one of the most important protocols that ISO 21001 standard focuses on.

$\square$ Only a few quality bodies focus on the need for a protocol for strategic planning and developmental vision of the institution, with identifying potential risks that may arise, identifying the necessary opportunities in the institution, and providing guarantees that the management system of the educational institution can achieve the desired results. This clause is one of the provisions applied during implementation of ISO 21001 standard.

In line with the ISO 21001 standard, quality bodies focus on the stakeholders and the relationship with the educational institution and organizations directly and indirectly related to the educational institution, and those external providers that provide direct and indirect services to the beneficiaries in the institution.

$\square$ Of course, the curriculum that is taught in the educational institution is the key driving element for measuring and developing the monitoring and evaluation system of the educational institution, and this protocol is considered one of the key requirements on which the ISO 21001 standard is based.

$\square$ All quality bodies require and impose on higher education institutions to define the goals, visions, and strategies governing their work, and this protocol is one of the protocols used and applied in the ISO 21001 system.

$\square$ Quality bodies focus on the infrastructure that the educational institution maintains, the structures and buildings that the educational institution includes, and the buildings and grounds that can help students and the direct beneficiaries. This protocol is available within the scope of ISO 21001 standard which includes adequacy, safety and appropriateness of the infrastructure as per ISO 21001.

$\square$ Some quality bodies specify the requirement for research and publication of research by the teaching staff of the educational institution, and this scheme is considered one of the prospects discussed by the ISO 21001 system. In addition, it also covers the aspects of plagiarism.

$\square$ Some quality bodies focus that the educational institutions need to conduct performance evaluations and research of the beneficiaries' satisfaction with the service and their view of the product they 
receive, in addition to the need to conduct permanent and frequent evaluations. This requirement is considered one of the main provisions of the ISO 21001 system. In addition, ISO 21001 focuses on an effective handling of complaints from the interested parties.

$\square$ The ISO 21001 standard focuses on the need to support and encourage creativity, innovation, cause analysis approach for problem solving and continual improvement which is to be treated as aproject. The ISO 21001 standard discusses in detail.

$\square$ The ISO 21001 standard encourages educational institutions to continuously improve their plans, programs, and strategies, and almost all quality bodies around the world share this point.

$\square$ ISO 21001 standard promotes and supports protocols related to persons with special needs and how to provide the best educational products and services for them. Some quality organizations in accordance with ISO 21001 focus on this provision. ISO 21001 talks about developing the individualized learning programs that specifically cater to the needs of special learners, capacity building of educators who are in direct contact with these learners and also regular monitoring of their learning outcomes.

\section{Key benefits of implementing an ISO 21001:2018 standard}

$\square$ Better alignment of objectives and activities with policy (including mission and vision);

$\square$ Enhanced social responsibility by providing quality education for all;

$\square$ Personalized learning and effective response to all learners, (including learners with special education needs);

$\square$ Consistent processes and evaluation tools to demonstrate and increase effectiveness and efficiency;

$\square$ Increased credibility of the organization;

$\square$ Demonstrate effective educational management practices;

$\square$ Culture for organizational improvement;

$\square$ Harmonization of other standards (in EOMS);

$\square$ Participation of interested parties;

$\square$ Stimulation of excellence and innovation.

\section{Findings, suggestions and recommendations}

$\square$ The implementation of the ISO 21001 standard contributes to having a positive impact on the work, structure, methodology, and systems of higher education and the mechanism of work of higher education institutions around the world. It also plays a similar impact to the impact played by quality assurance bodies around the world.

$\square$ The implementation of the ISO system contributes to the internationalization and globalization of higher education, which is the effect that leads to the unification of the systems of work of higher education institutions around the world in accordance with unified protocols and action plans at an international level, which in turn contributes to strengthening the educational process around the world. 
Higher education institutions can achieve quality assurance by communicating with quality agencies, or by communicating with a quality assurance body in accordance with ISO 21001 standard.

$\square$ As we have seen during the study, all quality bodies carry and share with the ISO 21001 standard about $80 \%$ of the standards and provisions regulating their work. As a result, we believe that there are no fundamental differences between the application of any of the previous systems of quality. Thus, no extra work may be required by the higher education institutes to implement ISO 21001

$\square$ The ISO 21001 standard is considered one of the recent standards, and for this reason, there is not enough awareness about the standard nor about the benefit it can achieve.

$\square$ We recommend that institutions that grant ISO 21001 certification increase workshops, trainings and educational courses that can contribute to raising awareness about the ISO 21001 standard as a standard similar to and simulate quality assurance bodies in all countries of the world.

$\square$ We advise all quality bodies around the world to submit some modifications to their standards so that they are compatible with the new conditions resulting from the COVID-19 pandemic.

$\square$ We advise higher education institutions to conduct studies related to the expected benefit of implementing the ISO 21001 standard, in a way that contributes to improving their work plans.

$\square$ We advise the quality professionals to share their feedback on the ISO 21001 standard with ISO through their National Standardization Bodies. This feedback can be considered in the next revision. ISO standards generally undergo revisions every 6-7 years.

\section{REFERENCES}

1. AACSB international. (n.d.). Retrieved July 17, 2021, from https://www.aacsb.edu/

2. ABET Accreditation. (n.d.). Retrieved July 17, 2021, from https://www.abet.org/accreditation/

3. Accreditation Agency Curacao. (n.d.). https://www.aac.cw/.

4. Accreditation Agency in Health and Social Sciences - AHPGS. (n.d.). Retrieved July 17, 2021, from https://ahpgs.de/en/about-us/

5. Accreditation Commission for Education in Nursing. (n.d.). Retrieved July 17, 2021, from https://www. acenursing.org/

6. Accreditation Council for Business Schools and Programs. (n.d.). https://acbsp.org/page/search_accredited.

7. Accrediting Commission for Community and Junior Colleges. ACCJC. (2021, July 12). https://accjc.org/.

8. Akkreditierungs-, zertifizierungs- \& qualitätssicherungs-institut. (2021, May 26). Retrieved July 17, 2021, from https://www.acquin.org/

9. AQAS E.V. - Agentur zur qualitätssicherung. (2021, April 06). Retrieved July 17, 2021, from https:// www.aqas.eu/

10. Campailla, C., Martini, A., Minini, F., \&amp; Sartor, M. (2019). 14. ISO 45001. Quality Management: Tools, Methods and Standards, pp. 217-243. DOI:10.1108/978-1-78769-801-720191014 
11. Certification, verification, assessment. (2020, October 28). Retrieved July 17, 2021, from https://iso26000. info/certification/

12. Council for Higher Education Accreditation. (n.d.). Retrieved July 17, 2021, from https://www.chea.org/

13. Education and TRAINING Evaluation Commission. (n.d.). Retrieved July 17, 2021, from https://www. etec.gov.sa/en/Pages/default.aspx

14. ENIC-NARIC. (n.d.). Retrieved July 17, 2021, from https://www.enic-naric.net/

15. European Quality Assurance Agency EQAA. (n.d.). Retrieved July 17, 2021, from https://eqaa.eu/en/ about/agency/

16. FSSC 22000. (2021, February 08). Retrieved July 17, 2021, from https://www.fssc22000.com/

17. Gilbert, D.D. 2020. ISO alongside, instead, or INSIDE? The potential of ISO 21001:2018 to change and challenge higher education accreditation. International Journal of Business and Applied Social Science, pp. 45-52. DOI:10.33642/ijbass.v6n10p5

18. Government of India, All India Council for technical Education |. (n.d.). Retrieved July 17, 2021, from https://www.aicte-india.org/

19. Higher Education Commission, Pakistan. (n.d.). Retrieved July 17, 2021, from https://www.hec.gov.pk/ english/pages/home.aspx

20. International Programme Accreditation. Acquin. (2021, February 4). https://www.acquin.org/en/ programmeaccreditation/.

21. ISO 13485 - medical devices. (2020, March 11). Retrieved July 17, 2021, from https://www.iso.org/ iso-13485-medical-devices.html

22. ISO 18091. (n.d.). Retrieved July 17, 2021, from https://iso18091.org/

23. ISO 20000: The international standard for service management. (n.d.). Retrieved July 17, 2021, from https://www.itgovernance.co.uk/iso20000

24. ISO 21001:2018. ISO. (2021, February 24). https://www.iso.org/standard/66266.html.

25. ISO 50001 - energy management. (2020, December 07). Retrieved July 17, 2021, from https://www.iso. org/iso-50001-energy-management.html

26. ISO 9000 family - quality management. (2020, March 11). Retrieved July 17, 2021, from https://www. iso.org/iso-9001-quality-management.html

27. Keltron. (n.d.). National Assessment and Accreditation Council (NAAC). Retrieved July 17, 2021, from http://www.naac.gov.in/

28. Kovalenko, S.M., Romelashvili, O.S., Zborovska, T.V., \&amp; Blagun, O.D. 2020. General aspects of introduction of management systems in educational organizations in pursuance of ISO 21001: 2018. Management, Economy and Quality Assurance in Pharmacy, 04(64): 4-9.

29. Marsden, E. (2017, July 31). The ISO 31000 standard risk management: Principles and guidelines. Retrieved July 17, 2021, from https://risk-engineering.org/ISO-31000-risk-management/ 
30. New England Commission of Higher Education. NECHE. (2021, June 10). https://www.neche.org/.

31. Pecb. (n.d.). ISO 20121 event sustainability management system trainings. Retrieved July 17, 2021, from https://pecb.com/en/education-and-certification-for-individuals/iso-20121.

32. Program Accreditation. Accreditation Agency Curacao. (n.d.). https://www.aac.cw/program-accreditation/.

33. Qccertification.com. (n.d.). ISO 29990:2010. Retrieved July 17, 2021, from https://qceertification.com/ iso-29990-2010.aspx

34. Research, M. (n.d.). Norwegian agency for quality assurance in education (nokut). Retrieved July 17 , 2021, from https://www.regjeringen.no/en/dep/kd/organisation/kunnskapsdepartementets-etater-ogvirksomheter/Subordinate-agencies-2/norwegian-agency-for-quality-assurance-i/id426568/

35. Sitio de Secretaría DE educación pública. (n.d.). Retrieved July 17, 2021, from https://www.gob.mx/sep

36. Standards for Accreditation - New England Commission of Higher Education. NECHE. (2021, January 3). https://www.neche.org/resources/standards-for-accreditation.

37. The Accreditation Service for International Schools, Colleges and Universities. (n.d.). Retrieved July 17, 2021, from https://www.asicuk.com/

38. The uk's Quality body for higher education. (n.d.). Retrieved July 17, 2021, from https://www.qaa.ac.uk/

39. Tohet, M., \&amp; Cahyono, D.E. (2019). Quality improvement of higher education OF Pesantren through ISO 21001: 2018. Didaktika Religia, 7(1): 166-185.

40. Tong, C.K., \&amp; Wong, E.T. (n.d.). ISO 27000 information security management system. Governance of Picture Archiving and Communications Systems, pp. 28-40. DOI: 10.4018/978-1-59904-672-3.

41. TRACCERT training accreditation and certification Organization, Canada. (n.d.). Retrieved July 17 , 2021, from https://www.traccert.org/

42. University Grants Commission. (n.d.). https://www.ugc.ac.in/.

43. Vasilevskyi, O. (2019). Higher education quality system in the context of the ISO 21001:2018 implementation. Measuring Equipment and Metrology, 80(4): 41-48.

44. What exactly is ISO certified? and why does it matter? (n.d.). Retrieved July 17, 2021, from https://www. meadmetals.com/blog/what-exactly-is-iso-certified-and-what-does-it-mean

45. What is ISO 14001:2015 - environmental management systems? (n.d.). Retrieved July 17, 2021, from https://asq.org/quality-resources/iso-14001.

46. Wibisono, Eric (2018). The new management system ISO 21001:2018: What and why educational organizations should adopt it. Proceeding of $11^{\text {th }}$ International Seminar on Industrial Engineering and Management, pp. 66-73. ISSN: 1978-774X

47. Wukonig.com. (n.d.). AQ Austria. Retrieved July 17, 2021, from https://www.aq.ac.at/de/

48. YÖK Yükseköğretim Kurulu Başkanlığı. YÖK Ana Sayfa. (n.d.). https://www.yok.gov.tr/. 